\title{
Historical information on common carp (Cyprinus carpio) in Norway
}

\author{
Einar Kleiven
}

Kleiven E. 2013. Historical information on common carp (Cyprinus carpio) in Norway. Fauna norvegica 33: $13-19$.

The common carp (Cyprinus carpio Linnaeus, 1758) is an introduced fish species in Norway over the past 300 years. Many attempts have been conducted in order to try to create self-sustaining populations, but the species is very rare. Several authors have asserted that carp was introduced by monks, but this is not documented. The first written reference to common carp in Norway is the often quoted information in Pontoppidan (1753). However, the oldest knowledge of common carp can now be dated back to about 1685. The first introduction took place in the Bergen area, western Norway.

doi: 10.5324/fn.v33i0.1583. Recieved: 2013-04-17. Accepted: 2013-06-01. Published online: 2013-12-20.

Keywords: Common carp, introduction, Norway

1. Norwegian Institute of Water Research (NIVA), Region South, Jon Lilletuns vei 3, NO-4879 Grimstad

Corresponding author: Einar Kleiven

E-mail:einar.kleiven@niva.no

\section{INTRODUCTION}

The common carp (Cyprinus carpio Linnaeus, 1758) (later called carp) is an introduced fish species in Norway (Collett 1905), and today has a scattered distribution in the southern part of the country (Kålås \& Johnsen 1995; Hesthagen 2012). Several attempts of introduction have been conducted over the last approximately 300 years in order to achieve reproducing populations (e.g. Pontoppidan 1753; Løvenskiold 1784; Collett 1875, 1905; Helland 1904; Huitfeldt-Kaas 1918; Harstad 1938). However, the knowledge of this fish species in Norway was very sparse until Kålås \& Johnsen (1995) published their article. In this paper additional information will be presented. In order to put this into a broader perspective, historical notes from other countries are also presented. The aim of this article is primarily to present historical knowledge about the carp in Norway.

Carp is native to areas from the Black Sea to Manchuria in China, but has been spread by humans to many parts of the world (Pethon 1994). It was introduced to Europe by the Romans.

\section{METHOD}

The information presented here is based on literature studies. In addition, I have received some personal information from a few persons.

Additional information to those outlined by Kålås \& Johnsen (1995) will be presented chronologically with UTM references (Table 1, Table 2).

Stocking of fish species in Norway is illegal without permission from the authorities, by the Act of 6 March 1964 about salmon fishing and inland fishing. However, increasing interest of angling carp in recent years has resulted in illegal introductions in many localities. People who have conducted such illegal stockings are reticent to tell about carp introductions. Some of these localities may, however, be found on the Internet. Recently, the carp distribution in Norway was mapped by Hesthagen \& Sandlund (2007) and Hesthagen (2012).

\section{The "monks theory"}

Kålås \& Johnsen (1995) refer to the common theory that monks introduced carp in the Nordic countries during the Catholic period (e.g. Krøyer 1846-1853; Huitfeldt-Kaas 1918; Wollebæk 1924; Sømme \& Jensen 1970; Pethon 1989, 1994). However, no irrefutable documentation has been presented for this theory. Jensen (1962) supported this idea, and L'Abée-Lund (1992) indicated import of carp around the year 1500, a period also suggested by Pethon $(1989,1994)$ and Hesthagen \& Sandlund (2007). Also pike (Esox lucius Linnaeus, 1758) has been ascribed to have been introduced by Danish monks in a small 
Norwegian lake called Rosholttjenna near Grimstad, AustAgder County (Andersen 1968). However, no monastery was located in this area (Lunde 1987). In the nearby Lake Temse, pike was introduced around 1735 (Kleiven \& Hesthagen 2012), a period which seems more reasonable for fish introduction in this areas. Pike was introduced before 1799 to a dam in the garden of the minor plant at Nes Verk (Helland 1904).

Contemporary authors in the 16th and first part of the 17th century (e.g. Magnus 1555; Berntsen 1656) stated that carp did not exist in the Nordic countries at that time.

\section{Some European notes}

According to Günther (1868) the first introduction of carp to Great Britain took place in 1614 .

However, "according to others" introduction should have taken place "already in 1521 or perhaps 1496". Carp did not come to Prussia (a German kingdom) until ca. 1769, according to Stuxberg (1859). Pennant (1766) reports that carp was introduced in Great Britain in 1514 by Leonard Maschal. However, Pennant (1766) has in a note, and Yarrel (1836) in the text, pointed out that carp is mentioned in the celebrated Boke of St. Albans, by Dame Luliana Barnes or Berners in 1496, where the species is characterized as a "deyntous fisshe" [delicious] (Berners 1496). According to Feddersen (1894) there were only a few localities having carp in Great Britain in 1496. At approximately the same time carp was introduced into France. The famous author Walton (1653) wrote that carp inhabited the British Isles approximately 100 years "or so" ago, i.e. about 1550. He refers to a poem of Sir Richard Bakers where the poet mentions that "carp, common hop, bear, and turkey" were imported at the same time. In the Privy Purse expenses of King Henry the Eight in 1532, various entries are made of rewards to persons for bringing "Carpes to the King" (Yarrel 1836).

\section{Notes from Sweden and Denmark}

In Sweden, carp was introduced in "monastery times", imported from Germany, according to Liljeborg (1891) and Stuxberg (1895), but no evidence of this exists. When carp ponds were established at the new-built Castle of Kalmar in 1572, German craftsmen and fish were brought from Germany (Bernström 1963). In 1734 carp imported from Germany was a common occurrence according to an announcement in "Then Swenska Argus" (Bernström 1981).

In Denmark monks are thought to have conducted comprehensive breeding of carps during the Catholic period (prior to 1536) (Stuxberg 1895). However, Feddersen (1894) suggests that carp breeding was rare before 1500 , and Otterstrøm (1914) writes that carp was probably not imported to Denmark in the "monastery time".

From 1560, carp breeding took place at Faurholm near Frederiksborg in (Denmark), and most likely Peder Oxe improved the carp breeding in the country by bringing back adult fish from France in the 1566 (Otterstrøm 1914; TroelsLund 1940). Peder Oxe imported carp and other "seldom" fish species (Holberg 1732-1735/II). The introduction took place approximately in 1560 to Skåne (Nilsson 1855), and in the rest of Denmark (Liljeborg 1891). According to Troels-Lund (1914), Peder Oxe "surely" introduced carp when he returned from exile in the autumn of 1566 , or he was probably at least one of the first (Ryge 1765). He became imperial chancellor in Denmark in 1567 and had several properties in Skåne (TroelsLund 1940). From these properties carp was spread to other farms in the region, where they had begun breeding activities (Liljeborg 1891). The many references to Peder Oxe as the man who introduced carp in Denmark in the 1560s, may be due to the fact that the species have been imported several times.

According to Resen (1680), King Frederik II (1534-1588) was the first person who imported carp, crawfish and "other seldom fish" to Denmark. In 1600, however, carp breeding took place at a large scale in Denmark (Feddersen 1894; Otterstrøm 1914). Knut Brahe, the owner of Engelsholm at Vejle, wrote that in September 1600 the Gammelby Pond was finished which he put carp into.

Krøyer (1846-1853) indicates that carp had been introduced in Denmark before Peder Oxe. He points to the fact that Schonevelde (1624) mentions carp in the southernmost regions Slesvig and Holsten, where the species must have been introduced long time before Peder Oxe did so. His statement is probably based on the expression "piscis lacustris et fluviatilis omnibus notus" [lake and river fish known to all] in Schonevelde (1624), referred to in Krøyer (1846-1853).

Thus, it appears certain that Peder Oxe not was the first person who imported carp to Denmark (Knud Larsen, former state biologist, pers. comm.).

In 1655, Berntsen (1656) wrote that Danish lakes, brooks and fish parks were rich in fish. He encountered altogether 14 fish species from different parts of Denmark, and usually carp is mentioned as the first species.

In Scandinavia, the carp was certainly a known species among people who had travelled in Europe even before the middle of the 16th century. The Latin fable collection Dyalogus creaturarum was the first printed book in Sweden (1483) (wikipedia.org), where a speaking carpio brags about sweetsmelling and delicious meat (Bernström 1963). A recipe brought home to Sweden from Venice about 1500 describes preparation of carp. In 1649, a German fish book was translated to Danish, where carp is described as a delicious and pleasant fish (Holst 1649). The exclusivity of carp is reflected in the second scientific name which Schonevelde (1624) gave the species: Cyprinus nobilis (Krøyer 1846-1853).

\section{Distribution of fish species in Norway}

In 1743, fish species are mentioned many places in answers on a query emitted from the royal court (e.g. Røgeberg 2004). From these answers, Elgmork (1956) found information of crucian carp Carassius carassius Linnaeus, 1758) in ponds and lakes of Ringerike, but none of the nine officials he referred to have mentioned carp. Before 1800, we have some other scattered 
observations of fish species, e.g. Berntsen (1656), Ramus (1735), Pontoppidan (1753), Hammer (1775) and Mumsen (1789), a Dutch traveller who wrote a diary when he travelled in Norway in 1788. Of the authors referred above, only Pontoppidan (1753) and Hammer (1775) mentioned carp, in Bergen and Jarlsberg (Vestfold), respectively. Neither had Wilse (1779) any carp locality in his own district, Spydeberg in Østfold. However, he was familiar with carp, a species he called ide (Leuciscus idus Linnaeus, 1758) or "false carp" because it tasted almost as carp did. (For a period in Eskilstuna in Sweden, the ide was called carp, probably due to unsuccessful introduction of carp (Bernström 1948; cf. Liljeborg 1891).

\section{Notes of carp introductions}

The first information of carp in Norway is given by Edvard Edvardsen in a manuscript from Bergen written in the period 1674-1694 (Nicolaysen 1868; cf. Edvardsen 1952; Kleiven 2007; cf. Table 1). In addition to carp, Edvardsen mentioned that crucian carp and pike inhabited lakes, dikes and ponds, but "it is not any great amount yet", because they had recently been introduced. This indicates that the introduction of one or more of these species may have taken place at that time. Crucian carp existed in Bergen prior to 1650, as Edvardsen tells about crucian carp and eel in a pond called "Kroppedam" near the "Castle", which dried out in 1649 (Nicolaysen 1868; cf. Edvardsen 1952; Kleiven 2007). The prefix name "kroppe" (= crucian carp) originates from southwest Sweden or Bornholm in Denmark, which indicates import of crucian carp from one of these two geographical areas long time ago (Kleiven 2007). Some other introductions of crucian carp, pike or tench (Tinca tinca, Linnaeus, 1758) from England or Europe are known from the southernmost areas of the country.

The first written information of crucian carp in Norway is from approximately 1530 (Seip 1936; Ree \& Wallem 1916). So it seems reasonable that it was carp (and pike?) which Edvardsen writes had been introduced into the Bergen area at that time (Nicolaysen 1868; cf. Edvardsen 1952). This information fits well with Berntsen (1656), born in Bergen, who categorically states that carp did not exist in Norway. According to Nicolaysen (1868) carp may have been introduced in the Bergen area approximately 1685 , which may be the first introduction to Norway. Earlier, the information given by Pontoppidan (1753) has been the oldest knowledge about carp in Norway (cf. Kålås \& Johnsen 1995).

Carp is also reported from Stend near Bergen. When Hans Hjort received privileges to the residence there in 1682, he had recently built a residential building at the farm (Myking 1990). In the ponds in the garden he put carp and

Table I. Some historical disclosures about carp in Norway to those published by Kålås \& Johnsen (1995). Text in italics is new information.

\begin{tabular}{|c|c|c|c|c|c|}
\hline Locality & Municipality & Year/period & Origin & Status today & References \\
\hline Ponds or dikes & Bergen & $1674-1694$ & & Extinct & $\begin{array}{l}\text { Nicolaysen (1868), cf. Edvardsen (1952), } \\
\text { Kleiven (2007) }\end{array}$ \\
\hline Stend & Fana & Ca. 1685 & & Extinct & Anonymous (1817), Fagerheim (2010) \\
\hline Unknown & Bergen & Ca. 1740 & Germany & Extinct ${ }^{1)}$ & Pontoppidan (1753), cf. Collett (1875) \\
\hline Jarlsberg, ponds ${ }^{2}$ & Tønsberg & $\begin{array}{l}<1775 \\
1898\end{array}$ & & $\begin{array}{l}\text { Extinct } \\
\text { Failed }\end{array}$ & $\begin{array}{l}\text { Hammer (1775) } \\
\text { Collett (1905) }\end{array}$ \\
\hline Fossum & Skien & $<1784$ & Denmark? & Extinct & Løvenskiold (1784), Jacobsen (1939) \\
\hline Milde & Bergen & Late 1700 & & Extinct & Collett (1875) \\
\hline Mosvollstjenna & Farsund & $\begin{array}{l}<1844 \\
\text { (Late 1700's?) }\end{array}$ & & Dense pop. & $\begin{array}{l}\text { Asbjørnsen (1844), Løberg (1864), Collett } \\
(1875,1905) \text {, own obs. 1993, Kålås \& } \\
\text { Johnsen (1995) }\end{array}$ \\
\hline Sjåen & Kragerø & 1897 or 1898 & Germany & $\begin{array}{l}\text { Lake was } \\
\text { drained in } 1970\end{array}$ & $\begin{array}{l}\text { Collett (1905), Huitfeldt-Kaas (1918), Kålås } \\
\text { \& Johnsen (1995) }\end{array}$ \\
\hline Husavatnet & Tysvcer & ca. 1910 & & Extinct? & Thor E. Håkonsen (pers. comm.) \\
\hline Semsvatn & Asker & 1927 & $\begin{array}{l}\text { Aneboda, } \\
\text { Sweden }\end{array}$ & Extinct & Harstad (1938, 1968), Sendstad (1962) \\
\hline Tredjedammen & Tønsberg & ca. 1945 & & Extinct(?) & Anonymous (2006) \\
\hline Nedre Stomner & Råde & 1956 & $\begin{array}{l}\text { Aneboda, } \\
\text { Sweden }\end{array}$ & & $\begin{array}{l}\text { Borgstrøm et al. (1990), } \\
\text { Dolmen (1991), Kålås \& Johnsen (1995) }\end{array}$ \\
\hline Pond/lake & Kragerø & 1970 & From Sjåen & $\begin{array}{l}\text { Few in number, } \\
\text { hybridize }^{3)}\end{array}$ & $\begin{array}{l}\text { Kålås \& Johnsen (1995), Andersen (1995), } \\
\text { Torfinn F. Andersen (pers. comm.) }\end{array}$ \\
\hline
\end{tabular}

1) Cf. text. 2) I assume that it is the same residential property as Jarlsberg Hovedgård where carp also was introduced in 1898 (Collett 1905). 3) Andersen (1995) reported hybrids (carp x crucian carp) of $3.48 \mathrm{~kg}$ and $4.68 \mathrm{~kg}$. 
crucian carp (Anonymous 1817; Fagerheim 2010). The carp introduced to Bergen about 1740 were hampered by poor growth and insects in the water (Pontoppidan 1753). It is highly probable that it disappeared fairly quickly. Hesthagen (2012) has only information about carp in one locality (Mildevatnet) in Hordaland County.

In a scattered overview on the Norwegian fish fauna Hammer (1775) mentions carp in ponds at Jarlsberg in Vestfold. He refers to the clergyman at Tønsberg, David Faye. Carp was also introduced to a pond at the Jarlsberg Hovedgård in 1898 (Collett 1905). I assume that these introductions are on the same residential property.

Import of carp fry to the Fossum residence in Skien is reported by Løvenskiold (1784). The owner, Herman Løvenskiold, established a zoo there in 1783 (Thue 1789). Fossum achieved rights to iron mining from approximately 1543, maybe the first rights given in Norway (Jacobsen 1939). The Løvenskiold family has been the owners of Fossum since 1739. Herman Løvenskiold received a diploma and gold medal from the Agricultural Society in 1784. One of the reasons was introduction of various fish species on his properties. The carps introduced to Fossum in 1783 came from Denmark (Løvenskiold 1784).
According to Collett (1875) the introduction of carp at the Milde farm near Bergen was undoubtedly conducted already "in the end of the previous century".

Lake Mosvolltjenna at Farsund in Vest-Agder, hosts a dense population of carp. The carp has been there for at last 130 years according to Kålås \& Johnsen (1995), who refer to Løberg (1864). Collett (1875) writes that the species had recently been introduced there. However, Asbjørnsen (1844) mentions carp "at Farsund" twenty years before Løberg (1864). The city of Farsund emerged in the late 1700's. Jochum Brinch Lund (17431807), considered as the city's founder, was a major commercial and industrial man who ran the extensive trade in many parts of Europe (Nilsen 2010). It is reasonable to assume that the carp population in Mosvolltjenna originate from this period, so the period the species has been an inhabitant may be extended to 220-230 years. This is still the oldest living carp population in Norway.

In Lake Semsvatn in Asker near Oslo, carp, tench (Tinca tinca Linnaeus, 1758) and whitefish (Coregonus lavaretus Linnaeus, 1758) were introduced in 1927 by the regional fishery inspector Joakim Harstad (Harstad 1938). Two and three years afterwards carps of 1.2 and $1.5 \mathrm{~kg}$, respectively, were caught, but no "fry have been seen". In the second half of the 1950s, a

Table 2. Localities mentioned in the text. Outlet position.

\begin{tabular}{lllll}
\hline Locality & County & Type of locality & UTM East & UTM North \\
\hline "Bergen" & Hordaland & Unknown dam & - & - \\
Rosholttjenna & Aust-Agder & Pond & 0474328.43 & 6468676.94 \\
Lake Temse & Aust-Agder & Lake & 0479139.07 & 6471921.14 \\
Nes Verk & Aust-Agder & Dam & 0491527.73 & 6498478.28 \\
Jarlsberg Manor & Vestfold & Filled dam & $(0579033.27$ & $6573041.35)$ \\
"Kroppedam" & Hordaland & Filled dam & 0297298.62 & 6701668.15 \\
Stend, Bergen & Hordaland & Filled dams & 0297070.84 & 6687558.15 \\
Mildevatnet, Bergen & Hordaland & Lake & 0293079.33 & 6684973.83 \\
Fossum & Telemark & Filled dam & 0532006.86 & 6567364.90 \\
Milde, Bergen & Hordaland & Filled dam & 0297102.36 & 6687529.18 \\
Mosvolltjenna & Vest-Agder & Pond & 0368532.52 & 6441538.97 \\
Lake Semsvatn & Akershus & Lake & 0579275.33 & 6636090.14 \\
Tredjedammen & Vestfold & Dam & 0580565.46 & 6572533.52 \\
Nedre Stomner & Østfold & Dam & 0601680.65 & 6581188.64 \\
Archbishop residence & S.-Trøndelag & Filled dam & 0569678.16 & 7033816.98 \\
Steinvikholmen & N.-Trøndelag & Filled dam & 0589836.14 & 7046750.57 \\
Karudsdammen, Austråt & N.-Trøndelag & Filled dam & 0536573.95 & 7064220.24 \\
Blakstad, Asker & Akershus & One dam & 0581802.69 & 6631759.11 \\
Munkedammen & Oslo & Filled dam & - & - \\
Husavatnet & Hordaland & Lake & 0303349.18 & 6589860.95 \\
Sjåen, Kragerø & Telemark & Lake & - & - \\
Kragerø & Telemark & Pond or lake & - & - \\
\hline
\end{tabular}


$10 \mathrm{~kg}$ carp was netted in the lake (Senstad 1962). This specimen may be one of the carps that was stocked in 1927, or more unlikely, a descendant from the 1927 stocking. In spite of the negative statement in Harstad (1938), he still mentions carp inhabiting the lake in a lexical review in 1968 (Harstad 1968).

In Tredjedammen close to Tønsberg, carp was put out there during World War II, according to Jørgen Mortensholm (Syrstad 2010). The carp lived "long and well", and several individuals were given name. The last surviving carp was called "Wanda", which had not been seen in a couple of years in 2010.

One other import from Aneboda, Sweden, took place in 1956 when carp was stocked in a pond in Østfold (Dolmen 1991).

\section{An old fish pond}

An excavation in 1992 at the Nidaros archbishop residence at Nidarosdomen in Trondheim revealed remnants of a cyprinid fish in an artificially built $4 \times 13 \mathrm{~m}$ pond (Nordeide \& Hufthammer 1993). They suggested that the remnants either were a carp or a crucian carp (Carassius carassius), thought to belong to the early sixteenth century. The cathedral Nidarosdomen was the most outstanding church in the Nordic countries in the Middle Ages. The last archbishop at Nidarosdomen was Olav Engelbriktsson, who resigned in 1537 when the Catholic Church lost its position. The fish pond was impossible to date by dendrochronological dating, but it is dated by stratigraphy and artefacts to the period ca. 1537-1590 (cf. Nordeide \& Hufthammer 2009). In the account books of Archbishop Olav Engelbriktsson from 1532-1538, his menu list is quoted (Seip 1936). On "fish days" the only freshwater fish species mentioned are crucian carp and dried pike.

The archbishop also built the castle at Steinvikholmen, a small island outside Trondheim (Wallem 1917). At a farm on the mainland a fish pond was established, where a field still is called Kardusåkeren. Kardus- is some places a local name for crucian carp (e.g. Blokkeskar 1984), and -åker is the Norwegian word for field.

The last part of the Catholic period in Norway was characterized by very unstable political conditions (Ree \& Wallem 1916). The archbishop came in conflict with the powerful lady Madame Inger to Austråt, who resided at her castle at the mouth of the Trondheimsfjord. In the early 1530s the archbishop's men attacked the castle. In order to save some pewter plates, Madame Ingers's servants threw them into a well and in a crucian carp pond called "Karudsdammen" (which means the crucian carp pond), where the archbishops men found them. From this incident we have lists over properties taken away from Austråt. This note of the crucian carp pond at Austråt, originated from before 1530 , is probably so far the first written notes of a fish pond in Norway.

Based on the present available knowledge of fish introductions in Norway, it seems reasonable that the remnant of the fish found in the excavated pond in Trondheim (Nordeide \& Hufthammer 1993) must have been a crucian carp.
In his history of the monasteries in Norway, Lange (1847) mentions fish ponds, but no fish species are specified. He states, without any reference, that the monks had done much for both distribution and breeding of the fish species by building fish ponds. Remains of some fish ponds at the farm Blakstad in Asker near Oslo was called Munkedammene. The farm had earlier belonged to a monastery in Bergen. Another farm in Oslo was called Munkedammen. According to Schia (1991) monks from Hovedøya monastery outside Oslo had fish ponds, "probably for carp fishes" he concludes without any references. Both names (Munkedammen(e)) mean "The monk's pond(s)", and originate probably from such fish ponds. The oldest known fish pond in Oslo was also called Munkedammen (Collett 1909). According to Wilse (1779) the pond had a size of $107 \mathrm{x}$ $50 \mathrm{~m}$ in his period, i.e. a quite big pond. According to Sandnes \& Stemshaug (1980), farms with the prefix "munk" in place names belonged to a monastery, or in a few cases, there was a monastery on the place.

This review shows that introductions of carp in Norway have been conducted for at least 300 years. All localities with introduced carp are close to the coast (cf. Kålås \& Johnsen 1995; Hesthagen \& Sandlund 2007; Hesthagen 2012).

\section{ACKNOWLEDGMENT}

Thanks to Øyvind Kaste for comments, Richard F. Wright for improving the English and to two anonymous reviewers.

\section{REFERENCES}

Andersen O. 1968. Rossholttjønna. In: Jensen KW. (ed.). Sportsfiskerens Leksikon. 2. Gyldendal Norsk Forlag. p 2049.

Andersen TF. 1995. Fiske fra fjord til fjell. Thure/Varden Forlag. $272 \mathrm{p}$.

Anonymous. 1817. Udkast til topografisk Beskrivelse over Fanøe Præstegjeld og Aarsta-Sogn i Bergen. Topografisk-Statistiske Samlinger. Anden Deels Første Bind. Christiania. pp 93-128.

Anonymous 2006. Byggeplaner ved Tredjedammen i Tønsberg. http://www.fiskersiden.no/forum/index.php?showtopic $=19373$ (Accessed 2012-05-3)

Asbjørnsen PC. 1844. Naturhistorie for Ungdommen. Tredie Deel. Krybdyrene og Fiskene (Med 58 Afbildninger). Forlagt af Guldberg \& Dzwonkowski. Trykt hos W.C. Fabritius, Christiania. $271 \mathrm{p}$.

Berners DJ. 1496. A Treatyse of Fysshynge wyth an Angle. Being a facsimile reproduction of the first book on the subject of fishing printed in England by Wynkyn de Worde at Westminister in 1496. With an Introduction by Rev. M.G. Watkins, M.A. Elliot Stock, 62, Paternoster Row, London, E.C. (1922). xiv +25 p.

Bernström J. 1948. Bidrag til känndom om några svenska fiskar i äldre tid. Fauna och flora 42: 35-46.

Bernström J. 1963. Karp. In: Hødnebø F. (ed.). Kulturhistorisk leksikon for nordisk middelalder fra vikingtid til reformasjonstid. 
Bind VIII. Judas-Konfiskation. Gyldendal Norsk Forlag, Oslo. pp 307-309.

Bernström J. 1981. Karp. In: Danstrup J. (ed.). Kulturhistorisk leksikon for nordisk middelalder fra vikingtid til reformasjonstid. Rosenkilde \& Bagger. København. 308 p.

Berntsen A. 1656. Danmarckis oc Norgis Fructbar Herligheds. Prentet i Kiøbenhavn aff Peder Hake/ Universitets Bogtr. Anno M. DC. LVI Paa Jørgen Holsts Bogf. Bekostning. Reprografisk genudgivet og forlagt af Selskabet for Udgivelse af Kilder til Dansk Historie. København 1971. 360+652 p + register.

Blokkeskar R. 1984. Sagn og halvglømte navn: fortellinger om folk som satte farge på bygdemiljøet. Nidaros forlag. $136 \mathrm{p}$.

Borgstrøm R, Hjelset S, Ravndal J. 1990. Karpe reproduserer i Norge. Fauna 43: 2-6.

Collett R. 1875. Norges Fiske, med Bemærkninger om deres Udbredelse. Tillægsh. til Vidensk. Selsk. Forh. f. 1874. Trykt hos A.W. Brøgger, Christiania. $240 \mathrm{p}+2$ plates +1 map.

Collett R. 1905. Meddelelser om Norges Fiske i Aarene 18841901. Chr.a. Vid. Selsk. Forh. for 1905. No 7). A.W. Brøggers Bogtrykkeri, Christiania. 173 p.

Collett A. 1909. Gamle Christiania Billeder. Ny udgave. J W. Cappelens Forlag, Christiania. 526 p.

Dolmen D. 1991. Dammer i kulturlandskapet - makroinvertebrater, fisk og amfibier i 31 dammer i Østfold. NINA Forskningsrapport 20: 1-63.

Edvardsen E. 1952. Bergen. Anden part. Utgitt av Bergen Historiske Forening Nr. 57/58 1951/1952. Ved Olav Brattegard. J.D. Beyer A/S Boktrykkeri, Bergen. 392 p.

Elgmork K. 1956. Om gjeddas innvandring i Randsfjord-Tyrifjordvassdraget. Særtrykk Fauna 1-1956. 10 p.

Fagerheim H. 2010. Stend - frå høvdingsete til representasjonsstad. Hordaland fylkeskommune. 27 p.

Feddersen A. 1894. Færskvandsfiskeriet. Anden forøgede udgave. P.G. Philipsens Forlag. Trykt hos Nielsens \& Lydiche. København. 170 p.

Günther A. 1868. Catalogue of the Fishes in the British Museum. Volume VII. Printed by order of the trustees, London. 512 p.

Hammer C. 1775. Forsøg til en Norsk Natur-Historie. I. Deel. Udgiven paa det Topographisk Selskabs Bekostning. Trykt hos H.C. Sander, Kiøbenhavn. 248 p.

Harstad J. 1938. Tiltak og hjelpemidler i fiskekulturens tjeneste. Driften av Sems-vannet. Fiskesport 11-1938: 200-201.

Harstad J. 1968. Askerelva. In: Jensen KW. (ed.). Sportsfiskerens Leksikon. 2. Gyldendal Norsk Forlag. col 1739.

Helland A. 1904. Topografisk-statistisk beskrivelse over Nedenes amt. Første del. Den almindelige del. Forlagt af H. Aschehoug \& Co (W. Nygaard), Kristiania. 660 p.

Hesthagen T. 2012. Karpe Cyprinus carpio. Faktaark, Artsdatabanken. Nr. 287. 3 p.

Hesthagen T, Sandlund OT. 2007. Non-native freshwater fish species in Norway: history, Consequences and perspectives. Journal of Fish Biology 71: 173-183.

Holberg L. 1733. Dannemarks Riges Historie. Tomus II. Trykt udi Hans Kongl. Majests. og Universitets Bogtrykkerie, af Johann Jørgen Høpffner. Kjøbenhavn. 922 p.

Holst B. 1649. En liden artig oc konstrig Fiske-Bog. I Kiøbenhaffn hos Jørgen Holst, B. tilkiøbs.Tryckt Aar 1649. 46 p.

Huitfeldt-Kaas H. 1918. Ferskvandsfiskenes utbredelse og indvandring i Norge med et tillæg om krebsen. Centraltrykkeriet.
Kristiania. 106 p.

Jacobsen R. 1939. Fossum Verks historie gjennem 400 år. Derav i slekten Løvenskiolds eie 1739-1939. I kommisjon hos Grøndahl \& Søn. 237 p.

Jensen K.W. 1962. Ørret som husdyr. Litt dambrukshistorie. Jakt, Fiske Friluftsliv. pp 158-162.

Kleiven E. 2007. Historiske opplysningar frå Bergen om karuss Carassius carassius, karpe Cyprinus carpio, brasme Abramis brama og gjedde Esox lucius. Fauna 60: 26-33.

Kleiven E, Hesthagen T. 2012. Fremmede fiskearter i ferskvann i Aust-Agder. Historikk, status og konsekvenser. NINA Rapport 665. 115 p. NIVA Rapport 12/001.

Krøyer H. 1846-1853. Danmarks Fiske. Tredie Bind. Trykt i S. Triers Officin, Kjøbenhavn. 1279 p.

Kålås S, Johansen R. 1995. The common carp (Cyprinus carpio L.) in Norway. Fauna norv. Ser. A 16: 19-28.

L'Abée-Lund JH. 1992. Karpefisker. In: Jonsson B. \& SembJohansson A. (eds.). Norges dyr. Fiskene 1. Krypdyr, amfibier, ferskvannsfisker. 2 opplag. J.W. Cappelens Forlag a.s. pp 151168.

Lange CCA. (1847). De norske klosters historie i Middelalderen, bearbeidet især efter utrykte Kilder. I Kommisjon hos Feiberg \& Landmark, Christiania. 827 p.

Lilljeborg W. 1891. Sveriges og Norges fiskar. Tredje delen. W. Schultz, Upsala. 830 p.

Lunde Ø. 1987. Norges klostre i middelalderen. Foreningen til norske fortidsminners bevaring, årbok 1987. pp 85-119.

Løberg ON. 1864. Norges Fiskerier. B.M. Berntzens Bogtrykkeri, Kristiania. 323 p.

Løvenskiold BH. von 1784. Beskrivelse over Bratsberg Amt og Scheens Bye med sine Forstæder. Christiania 1784 paa Bogtrykker Bergs Forlag. 285 p.

Magnus O. 1555. Historia om de nordiske folken. Gidlunds 1982, faksimilupplaga efter Michaelisgillets första svenska utgåva, illustrerad efter originalupplagans träsnitt, förord av Mats Rehnberg. (8)+II $+1087+15$ p.

Mumsen J. 1789. Tagebuch einer Reise nach dem südlichen Theil von Norwegen im Sommer 1788. Hamburg und Kiel, bey Carl Ernst Bohn 1789. 296 p.

Myking JR. 1990. Fana bygdebok. 2. Bønder nær byen 1665-1870. Utgjeven av Fanabygdeboknemnd. 562 p.

Nicolaysen N. 1868. Edvardsens Bergens beskrivelse. 1674-1694. In: Nicolaysen, N. (ed.). Norske magasin. Skrifter og optegnelser angaaende Norge og forfattede efter reformationen. Andet Bind. Johan Dahls Forlag, Christiania. pp 489-676.

Nilsen JE. 2010. Farsund. http://www.snl.no/Farsund (Accessed 2010-11-21).

Nilsson S. 1855. Skandinavisk fauna. Fjerde delen: Fiskarna. Lund. $768 \mathrm{p}$.

Nordeide SW, Hufthammer AK. 1993. Fiskedam i Erkebispegården. Spor 8: 44-45.

Nordeide SW, Hufthammer AK. 2009. Fishponds as garden features: the example from the Archbishop's Palace, Trondheim. Edpuglia s.r.l., pp 277-282.

Otterstrøm CV. 1914. Fisk II. Blødfinnefisk. Danmarks Fauna, Bd. 15. G.E.C. Gads Forlag, København. 351 p.

Pennant T. 1766. British Zoology. Vol. III. Warrington: Printed by William Eyres, for Benjamin White, at Horace's Head, Fleet Street, London MDCCLXXVI. 371 p. + errata + plates. 
Pethon P. 1989. Aschehougs store Fiskebok. Alle norske fisker i farger. 2. utgave. Aschehoug, Oslo. 447 p.

Pethon P. 1994. Aschehougs store Fiskebok. Alle norske fisker i farger. Aschehoug, Oslo 447 p.

Pontoppidan E. 1753. Norges naturlige Historie. Kongelig Waysenhuses Bogtrykkerie, København 1753. (Nyopptrykk i fotolitografi. Rosenkilde og Bagger, København 1977). 464 p + register.

Ramus J. 1735. Norriges Beskrivelse. Trykt udi H.K. Majstes. og Univ. Bogtrykkerie, af J.J. Høpffner. 274 p.

Ree LH, Wallem FB. 1916. Østraat. Opmaalinger, tegninger og bygningsbeskrivelse samt en utsigt over Østraats historie. F. Bruns Boghandels Forlag, Trondhjem. 85 p.

Resen PH. 1680. Kong Frederichs den Andens Krønicke: som var Dannemarckis, Norgis, ... etc. Konge og regierede lofligen i 29 Aar fra Aar 1559 til Aar 1588, ... /samlet oc sammenskrefvet af adskillige Codicibus M.S.S. oc med Figurer i kobberstik beprydet / ved Peder Hansøn Resen. København. 470 p. + ill.

Ryge AR. 1765. Peder Oxes til Gisselfeld Danmarks Riges Raads og Hofmesters Liv og Levnets Beskrivelse, af mange authentiqve Breve og Documenter. Trykt hos Nicolaus Møller, Kiøbenhavn. (29) $+436+12 p$.

Røgeberg KM. 2004. Norge i 1743. Innberetninger som svar på 43 spørsmål fra Danske Kanselli. 2 Akershus Stift Hedmark Oppland. Riksarkivet / Solum Forlag. 447 p.

Sandnes J, Stemshaug O. 1980. Norsk stadnamnleksikon. 2. utgåva. Det Norske Samlaget, Oslo. 362 p.

Schia E. 1991. Oslo innerst i Viken. Liv og virke i middelalderbyen. Aschehoug. Utgitt i samarbeid med Riksantikvaren og Oldsaksamlingen. $217 \mathrm{p}$.

*Schonevelle 1624. Ichthyologia. Hamburg. (Not seen, cited by Krøyer (1846-1853)

Seip JA. 1936. Olav Engelbriktssons rekneskapsbøker 1532-1538. Utgjevne av Noregs Riksarkiv, Oslo. 227 p.

Senstad C. 1962. Karpe og karuss. Fiskesport 1: 19-20.

Stuxberg A. 1895. Sveriges och Norges fiskar. Wettergren \& Kerber, Göteborg. 678 p.

Syrstad S-E. 2010. Altoppslukende. http://tb.no/arkiv/ altoppslukende-1.1409352_(Accessed 2012-05-3)

Sømme S, Jensen KW. 1970. Karpe- og mallefiskene. In: Frislid R, Semb-Johansson A. (eds.). Norges dyr 3. J.W. Cappelens Forlag a.s., Oslo. pp 140-151.

Thue FW. 1789 Forsøg til Beskrivelse over Kragerøe Kiøbsted og Langesunds-Fiorden, eller Scheens Kiøbsted med dens Ladesteder, samtlig beliggende i Bradsberg Amt og Aggershuus Stift i Norge. Kbh. 184p.

Troels-Lund T. 1940. Daglig liv i Norden i det sekstende århundre. Norsk utgave av Haakon Shetelig. Bind II. Gyldendal Norsk Forlag, Oslo. $771 \mathrm{p}$.

Wallem FB. 1917. Steinvikholm. Erkebisp Olav Engelbrektssøns fasle slot. F. Bruns Boghandels Forlag, Trondhjem. $106+$ (1) p.

Walton I. 1653. Den fullendte sportsfisker. Første del. J.W. Cappelens Forlag. (The complete angler, London 1653). 282 p.

Wilse JN. 1779. Physisk, oeconomisk og statistisk Beskrivelse over Spydeberg Præstegield og Egn i Aggerhuus Stift i Norge. Trykt i Christiania 1779 af C.S. Schwach. Utgitt på nytt i 1990 av Valdisholm forlag, Rakkestad. 588 p. + plates.

Wollebæk A. 1924. Norges fisker. Utgitt på foranstaltning av Zoologisk museum. Trykt i A.W. Brøggers boktrykkeri A/S.
$239 \mathrm{p}$.

Yarrel W. 1836. History of British Fishes. I. John van Voorst, 3, Paternoster Row, London. 408 p.

Editorial responsibility: Jan Davidsen.

This article is open-access and distributed under the terms of the Creative Commons Attribution-Noncommercial 3.0 Unported License (http://creativecommons.org/licenses/by-nc/3.0/). This permits all non-commercial use, distribution, and reproduction in any medium, provided the original work is properly cited. 